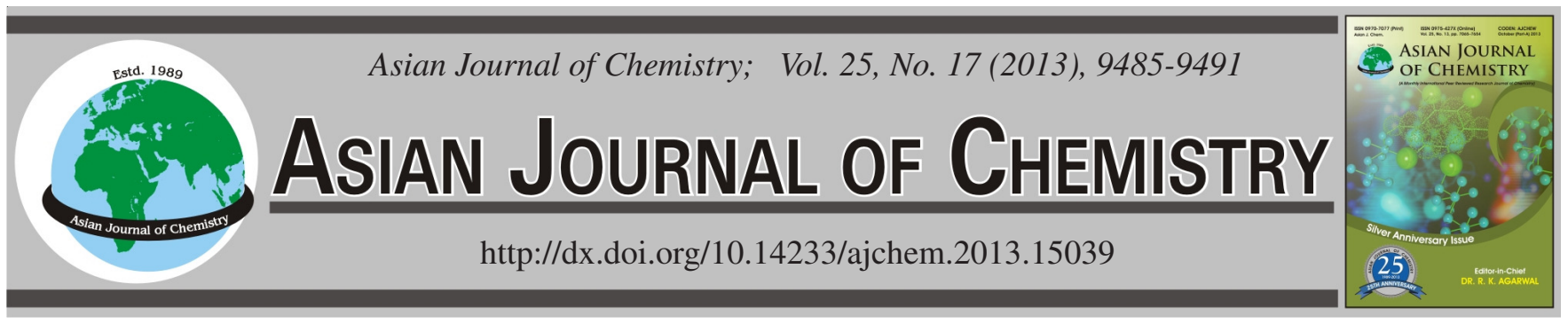

\title{
Extraction Optimization and Functional Properties of Protein from Amygdalus pedunculatus Seeds
}

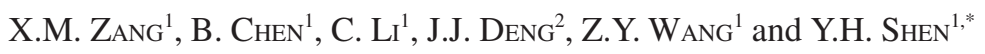

${ }^{1}$ Key Laboratory of Synthetic and Natural Functional Molecule Chemistry of Ministry of Education/College of Chemistry and Materials Science, Northwest University, 229 Taibai North Road, Xi'an 710069, P.R. China

${ }^{2}$ School of Chemical Engineering, Northwest University, 229 Taibai North Road, Xi'an 710069, P.R. China

*Corresponding author: Fax: +86 29 88302604; Tel: +86 29 88302716; E-mail: yhshen@nwu.edu.cn; zangxiaomei_0926@163.com

\begin{abstract}
Amygdalus pedunculatus seeds contain good-quality proteins. In this paper, maximum yield (55.85\%) was obtained when temperature, extraction time and liquid/solid ratio were $39.49^{\circ} \mathrm{C}, 80 \mathrm{~min}$ and $15.88: 1(\mathrm{v} / \mathrm{w})$ by using response surface methodology. The amino acid composition of Amygdalus pedunculatus seed protein was analyzed and the proportion of the essential amino acids was closer to the FAO recommended values, among which, glutamic acid was in a particular high level (25.24\% of total amino acid content). The maximum and minimum protein solubility of Amygdalus pedunculatus seed protein were found at $\mathrm{pH} 10$ and $\mathrm{pH} 4$. Water and oil absorption capacity were $2.20 \mathrm{~mL} \mathrm{H} \mathrm{H}_{2} \mathrm{O} / \mathrm{g}$ protein and $2.70 \mathrm{~mL}$ oil/g protein. Foaming capacity and emulsifying activity of Amygdalus pedunculatus seed protein were affected by $\mathrm{pH}(2-10)$. The least gelation concentration and surface hydrophobicity $\left(\mathrm{S}_{0}\right)$ were $12 \%$ and 290 , respectively. These results indicated that Amygdalus pedunculatus seed protein as a potential ingredient could be used in the food industry.
\end{abstract}

Key Words: Amygdalus pedunculatus seed, Response surface methodology, Protein, Functional property.

\section{INTRODUCTION}

The proteins from two major sources (animal proteins and plant proteins) are most widely used in the food and non-food markets, either as a general nutrients supply or as functional ingredients ${ }^{1}$. However, proteins from animal sources (milk proteins) are expensive and low production. Demand of relatively inexpensive sources of proteins that can be incorporated to value-added food products is increasing ${ }^{2}$. Worldwide, much of the research is going on various sources of plant proteins that may help in increasing the nutritional value of food products at low cost ${ }^{3-6}$.

Amygdalus pedunculatus (AP) is a rosaceous deciduous shrubs, low-input trees mainly grown in northwestern China and Mongolia. The leaves of this plant are spindle shape and have waxiness on its surface (Fig. 1). As a deciduous shrubs plant, it has a lot of rotted vegetation which can effectively improve the soil quality. The water and soil resources' protection and ecological balance around the desert areas were signally improved by the extensive root system of Amygdalus pedunculatus. Since the huge ability of preventing and controlling desert areas, Amygdalus pedunculatus has received considerable attention in recent years and has planted a lot in China. Meanwhile, a mass of Amygdalus pedunculatus seed (APS) were reaped every year and most of them were scrapped.

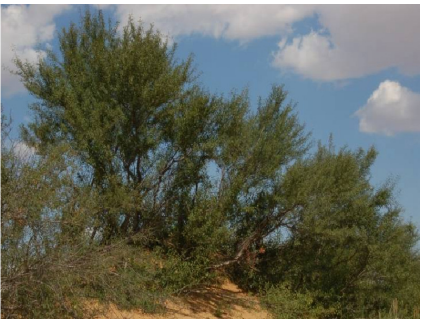

(A)

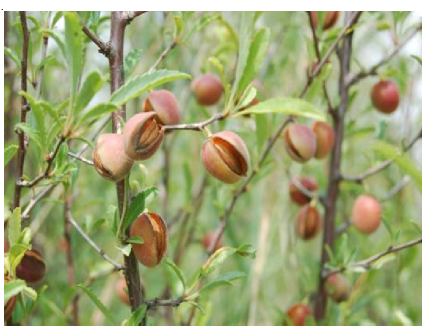

(C)

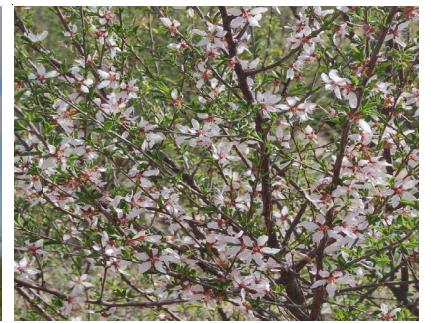

(B)

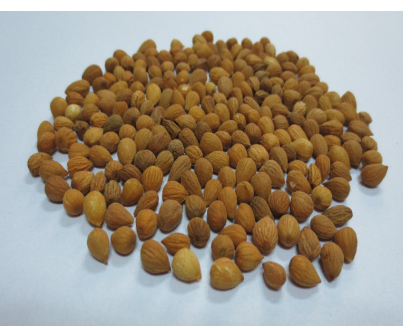

(D)
Fig. 1. A Amygdalus pedunculatus trees; B Amygdalus pedunculatus blooming; C Amygdalus pedunculatus fruiting; D Amygdalus pedunculatus seeds

This would cause the waste of resource. However, our research has found that Amygdalus pedunculatus seed was rich in protein and at present no scientific information is available on the 
protein from Amygdalus pedunculatus seed. Thus, it was deserved us to do further research. As known to all, to develop dietary protein for utilization as ingredients in the food industry, it is necessary to determine the physicochemical and functional properties of the extracted proteins ${ }^{7}$.

The objective of the present study was to evaluate the extraction condition, physicochemical and functional properties of Amygdalus pedunculatus seed protein. The amino acid composition, water/oil absorption, protein solubility, foaming and emulsifying properties, gelling properties and surface hydrophobicity, were reported to evaluate the quality of extracted protein isolates. The basic information about the physicochemical properties of isolates that would help to determine their application in foods was provided ${ }^{8}$.

\section{EXPERIMENTAL}

Sample preparation: Amygdalus pedunculatus seed were dehulled to get kernels and then smashed by a high speed grinder (WND-200, Wei neng da,China). The ground kernels lipids were removed by cold squeeze method and extracted two times with ethanol ratio (flour ethanol of 1:5 w/v) to remove residual lipids. The organic solvent was recycled by a rotary evaporator (RE-5205, Ya rong, China). The deoiled meal samples were grounded again and sieved to an uniform particle size. The samples were stored at $-20{ }^{\circ} \mathrm{C}$ till use. All other materials and reagents were of analytical grade and purchased from regular suppliers. The experiment was carried out in triplicate.

Proximate analysis: Association of Official Analytical Chemists AOAC (1997) methods were used to determine moisture, fat, protein, ash and fiber content.

Extraction of protein using response surface methodology (RSM): The defatted Amygdalus pedunculatus seeds (DAPS) were extracted with distilled water at varying temperature $\left(\mathrm{x}_{1}\right)$, reaction time $\left(\mathrm{x}_{2}\right)$ and liquid: solid ratio $\left(\mathrm{x}_{3}\right)$ by using response surface methodology (Table-1). According to the experimental data and Design-Expert 7.1.6 software analysis, the optimum protein extraction condition could be selected $^{9-11}$. The suspension was centrifuged at $10,000 \mathrm{~g}$ for $20 \mathrm{~min}$ and the supernatants were collected. The supernatants were adjusted to $\mathrm{pH} 4$ (Amygdalus pedunculatus seed protein' isoelectric $\mathrm{pH}$ ) and centrifuged at 10,000 $\mathrm{g}$ for $10 \mathrm{~min}$. Then collected precipitation and freezed drying. And protein samples were stored at $4{ }^{\circ} \mathrm{C}$ until used for the determination of physicochemical and functional properties.

\begin{tabular}{lcccc} 
TABLE-1 \\
INDEPENDENT VARIABLE VALUES OF THE \\
PROCESS AND CORRESPONDING LEVELS \\
\cline { 3 - 5 } Independent variables & \multirow{2}{*}{ Symbol } & \multicolumn{3}{c}{ Levels } \\
\cline { 3 - 5 } & & 30 & 0 & 1 \\
\hline Temperature $\left({ }^{\circ} \mathrm{C}\right)$ & $\mathrm{x}_{1}$ & 70 & 90 & 50 \\
Extraction time (min) & $\mathrm{x}_{2}$ & $10: 1$ & $15: 1$ & $20: 1$ \\
Liquid: solid ratio (v/w) & $\mathrm{x}_{3}$ & &
\end{tabular}

Amino acid analysis: Amino acid profiles were determined at the Pony Testing International Group chemical labs using AOAC Official Method 994.12.

Water/oil absorption: The water or oil absorption was determined by using a modified method described by Cao et al. ${ }^{12}$. Samples $(1 \mathrm{~g})$ were mixed with distilled water or peanut oil $(10 \mathrm{~mL})$ and the mixtures were centrifuged at $3000 \mathrm{~g}$ for $0.5 \mathrm{~h}$. Then the remaining water/oil's volume was measured and the water/oil capability could be calculated. The gain in volume per unit weight was recorded as water or oil absorption capacity.

Protein solubility (PS): Protein solubility was studied using a modified method of Shand et al..$^{13}$. Every $20 \mathrm{~mL}$ distilled water were mixed with each samples $(0.20 \mathrm{~g})$ and adjusted to $\mathrm{pH}$ (2-10) by using $1 \mathrm{~mol} / \mathrm{L} \mathrm{HCl}$ or $1 \mathrm{~mol} / \mathrm{L} \mathrm{NaOH}$. Samples were stirred in an orbital shaker at ambient temperature for $0.5 \mathrm{~h}$ and then centrifuged at $3000 \mathrm{~g} 10 \mathrm{~min}$. The protein content of supernatants was tested by the method of Kjeldahl and the protein solubility could be calculated.

Foaming properties (foaming capacity and stability): The foaming capacity (FC) and foaming stability (FS) of the protein were evaluated according to the modified method of Lin et $a l .{ }^{14}$. A sample $(1 \mathrm{~g})$ was mixed with $100 \mathrm{~mL}$ distilled water and the mixture was homogenized for $1 \mathrm{~min}$ by a Waring Blender (ds-1, Biao ben, China) at a certain speed (approximately $10,000 \mathrm{rpm}$ ). The mixture was transferred into a $250 \mathrm{~mL}$ graduated cylinder, so as to measure the foam volume. The foaming capacity was described as the increased percentage of volume at $\mathrm{pH}$ 7. Foaming stability was determined by measuring the decrease in volume of foam after $0.5 \mathrm{~h}$ at $\mathrm{pH} 7$.

Emulsifying properties (emulsifying activity and stability): The emulsifying activity (EA) and emulsifying stability (ES) were determined by using a modified method of Naczk et al. ${ }^{15}$. Distilled water $(50 \mathrm{~mL})$ was mixed with samples $(2.00 \mathrm{~g})$ and the mixture was homogenized for $1 \mathrm{~min}$ by using a Waring Blender at a certain speed (10,000 rpm). An equal quantity of peanut oil was added and mixtures were homogenized at another certain speed $(12,000 \mathrm{rpm})$ for $1 \mathrm{~min}$ again. The emulsion was divided evenly into $50 \mathrm{~mL}$ centrifuge tubes and centrifuged at $3000 \mathrm{~g}$ for $5 \mathrm{~min}$. Emulsifying activity could be deduced by the ratio of the height of the emulsified layer to the liquid layer at $\mathrm{pH}$ 7. Then the emulsion was heated $15 \mathrm{~min}$ at $85{ }^{\circ} \mathrm{C}$ and cooled $15 \mathrm{~min}$. The emulsifying stability was expressed as the percentage of emulsifying activity remaining after heating.

Gelling properties: The gelling properties of Amygdalus pedunculatus seed protein was described according to the method of Sathe and Salunkhe with some modification ${ }^{16}$. Different amounts of protein were weighed into $50 \mathrm{~mL}$ test tubes which contained $20 \mathrm{~mL}$ distilled water and made protein suspensions from $2-16 \%$. The $\mathrm{pH}$ was adjusted to 7 . Test tubes were heated in water bath at $85^{\circ} \mathrm{C}$ for $20 \mathrm{~min}$ and cooled immediately. Then cooled at $4{ }^{\circ} \mathrm{C}$ overnight. The least gelation concentration (LGC) was denoted as the concentration when the sample did not skid along the test tube walls in inverted $\operatorname{position}^{17}$. The results were expressed as liquefied (-), gluey $( \pm)$ and gel $(+)^{8}$.

Surface hydrophobicity $\left(\mathbf{S}_{\mathbf{0}}\right)$ : Surface hydrophobicity of protein was determined by using a hydrophobic fluorescence probe, 1-anilino-8-naphthalene sulfonate (ANS), with the help of a spectrofluorometer (RF-5301PC, Shimadzu, Japan). Amygdalus pedunculatus seed protein solutions of 0.15-0.30 $\mathrm{mg} / \mathrm{mL}$ were prepared using $0.01 \mathrm{M}$ phosphate buffer $(\mathrm{pH} 7)$ 
by serial dilution. Protein solutions of $2.0 \mathrm{~mL}$ were mixtured with ten microliters of $8.0 \mathrm{mM} 1$-anilino-8-naphthalene sulfonate solution (prepared in $0.01 \mathrm{M}$ phosphate buffer, $\mathrm{pH}$ 7). The fluorescence intensity was measured at wavelengths of $390 \mathrm{~nm}$ (excitation) and $470 \mathrm{~nm}$ (emission) by a spectrofluorometer. According to the plotted slope of fluorescence intensity against protein concentration, surface hydrophobicity was calculated by linear regression ${ }^{18}$.

Statistical analysis: The Design-Expert 7.1.6 software set up the design of response surface methodology and analysis of the maximum protein extraction under the optimum conditions. All trials were carried out in triplicate and all data were reported as means \pm SD (standard deviation). Treatment differences were evaluated at the $95 \%$ confidence level with three treatment replicates.

\section{RESULTS AND DISCUSSION}

Proximate composition of Amygdalus pedunculatus seed: The composition of Amygdalus pedunculatus seed was as follows (\% w/w): protein, 28.6; fat, 43.2; moisture, 6.0; ash, 2.5; fiber, 15.2. Amygdalus pedunculatus seed was rich in protein when compared favorably with other seeds as a potential non-conventional source of protein such as green lentils $(23.0 \mathrm{~g} / 100 \mathrm{~g})^{19}$, paprika seed $(24.43 \mathrm{~g} / 100 \mathrm{~g})^{20}$, red lentils $(25.9 \mathrm{~g} / 100 \mathrm{~g})^{19}$, desi chickpea $(20.5 \mathrm{~g} / 100 \mathrm{~g})^{19}$, yellow pea $(21.09 \mathrm{~g} / 100 \mathrm{~g})^{19}$, peanut $(22.04 \mathrm{~g} / 100 \mathrm{~g})^{21}$ and kabuli chickpea $(16.7 \mathrm{~g} / 100 \mathrm{~g})^{19}$. In brief, Amygdalus pedunculatus seed was a kind of potential plant protein resource and very worth studying.

Optimization for protein extraction using response surface methodology: Response surface methodology was selected to investigate optimum conditions for maximizing the yield of protein extraction from Amygdalus pedunculatus seed. The influences of temperature, extraction time and liquid: solid ratio on the experimental and predicted yield values of the protein extraction were depicted in Table-2. The coefficient of determination $\left(\mathrm{R}^{2}\right)$ was $86 \%$ and the standard error was 0.927 which indicates the adequate of applied model. The response surfaces based on these coefficients with one variable was at the optimum level and varying the other two within the experimental range were shown in Fig. 2. In general, the exploration of response surfaces demonstrated a complex interaction between the variables. Optimum protein extraction was obtained at $39.49^{\circ} \mathrm{C}, 80 \mathrm{~min}$ extraction time and 15.88:1 (v/w) liquid: solid ratio. Under this condition, the protein yield of theoretical value was $57.30 \%$, the actual protein yield could reach $55.85 \%$ and protein content is $94.8 \%$. It was observed that experimental optimal value was slightly lower than predicted value by the regression model. It confirmed that these conditions were optimal for Amygdalus pedunculatus seed protein extraction. The protein was extracted using the optimal condition and then analysised its amino acid composition.

Amino acid composition: The amino acid composition of Amygdalus pedunculatus seed protein has been quantified and the results were shown in Table-3. Amino acid composition of Amygdalus pedunculatus seed protein was partially conformed to the FAO requirements for the amino acids (FAO/WHO/ ONU, 1985) except for lysine, histidine and methionine + cysteine, while SPI was also partially satisfied with the standard. However, Amygdalus pedunculatus seed protein could be considered as a high quality protein which contains 18 kinds of amino acids. The total amino acid contents of Amygdalus pedunculatus seed protein was $94.75 \%$, slightly higher in comparison with SPI $(91.69 \%)$ and tea protein $(77.31 \%)^{22}$. Glutamic acid was the most abundant amino acid in Amygdalus pedunculatus seed protein, followed by aspartic acid, arginine, leucine, phenylalanine and glycine. The least abundant amino acid in Amygdalus pedunculatus seed protein was methionine, which only accounts for $0.8 \%$. The glutamic acid was widely used as pharmaceuticals, liver function promoting agents and fatigue recovery agents. Aspartic acid could promote the red blood cells grow and improve the nutrition of brain cells. It can be seen that Amygdalus pedunculatus seed protein was full of nutriments and deserved to do functional property research.

Absorption properties: Protein structure has both hydrophilic and hydrophobic properties and thereby interacts with water/oil in the food system ${ }^{23}$. Under limited water/oil conditions, the water and oil absorption capacity symbolizes the ability of binding water/oil molecules. The water and oil's

TABLE-2

BOX-BEHNKEN DESIGN ARRANGEMENT, RESPONSES AND PREDICTED VALUES FOR PROTEIN YIELD

\begin{tabular}{|c|c|c|c|c|c|c|c|c|}
\hline \multirow{2}{*}{ Run } & \multicolumn{3}{|c|}{ Coded variables } & \multicolumn{3}{|c|}{ Uncoded variables } & \multicolumn{2}{|c|}{ Protein yield $(\%)$} \\
\hline & $\mathrm{x}_{1}$ & $\mathrm{x}_{2}$ & $\mathrm{x}_{3}$ & $\mathrm{x}_{1}$ & $\mathrm{X}_{2}$ & $\mathrm{X}_{3}$ & Experimental & Predicted \\
\hline 1 & -1 & 0 & 1 & 30 & 60 & 20 & 51.84 & 51.19 \\
\hline 2 & 1 & -1 & 0 & 50 & 40 & 15 & 54.82 & 55.25 \\
\hline 3 & -1 & 0 & -1 & 30 & 60 & 10 & 45.59 & 55.48 \\
\hline 4 & -1 & 1 & 0 & 30 & 80 & 15 & 55.91 & 55.28 \\
\hline 5 & 0 & 0 & 0 & 40 & 60 & 15 & 54.44 & 47.49 \\
\hline 7 & 0 & 1 & -1 & 40 & 80 & 10 & 53.48 & 51.78 \\
\hline 8 & 0 & 0 & 0 & 40 & 60 & 15 & 57.11 & 52.81 \\
\hline 9 & 0 & 0 & 0 & 40 & 60 & 15 & 56.99 & 48.11 \\
\hline 10 & 1 & 0 & -1 & 50 & 60 & 10 & 50.26 & 52.01 \\
\hline 11 & 1 & 1 & 0 & 50 & 80 & 15 & 53.86 & 53.24 \\
\hline 12 & 0 & -1 & -1 & 40 & 40 & 10 & 49.59 & 54.66 \\
\hline 13 & 0 & 1 & 1 & 40 & 80 & 20 & 54.17 & 56.26 \\
\hline 15 & 0 & 0 & 0 & 40 & 60 & 15 & 56.11 & 56.26 \\
\hline 16 & -1 & -1 & -1 & 30 & 40 & 15 & 52.61 & 56.26 \\
\hline 17 & 0 & -1 & 1 & 40 & 40 & 20 & 51.76 & 56.26 \\
\hline
\end{tabular}




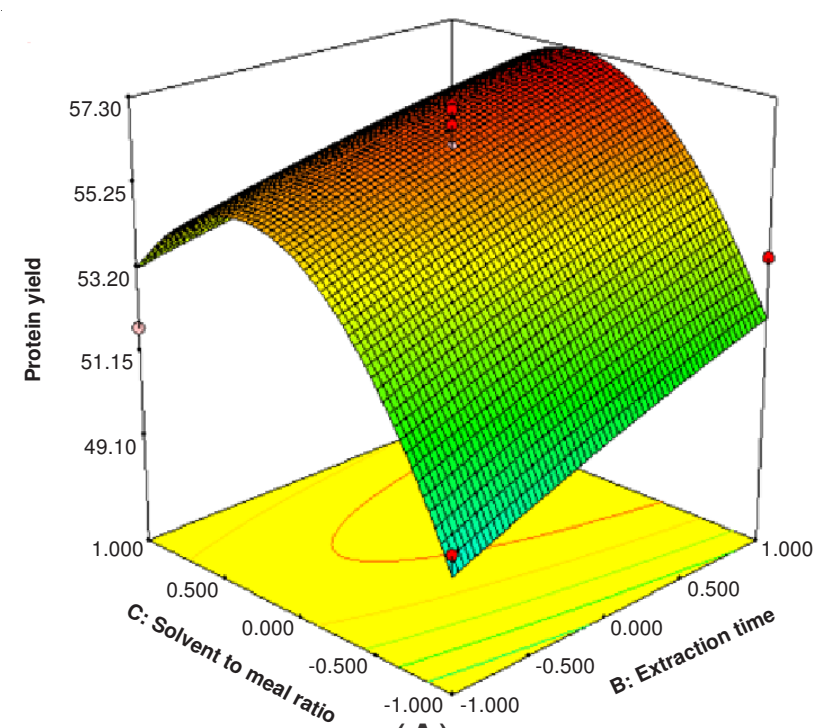

(A)

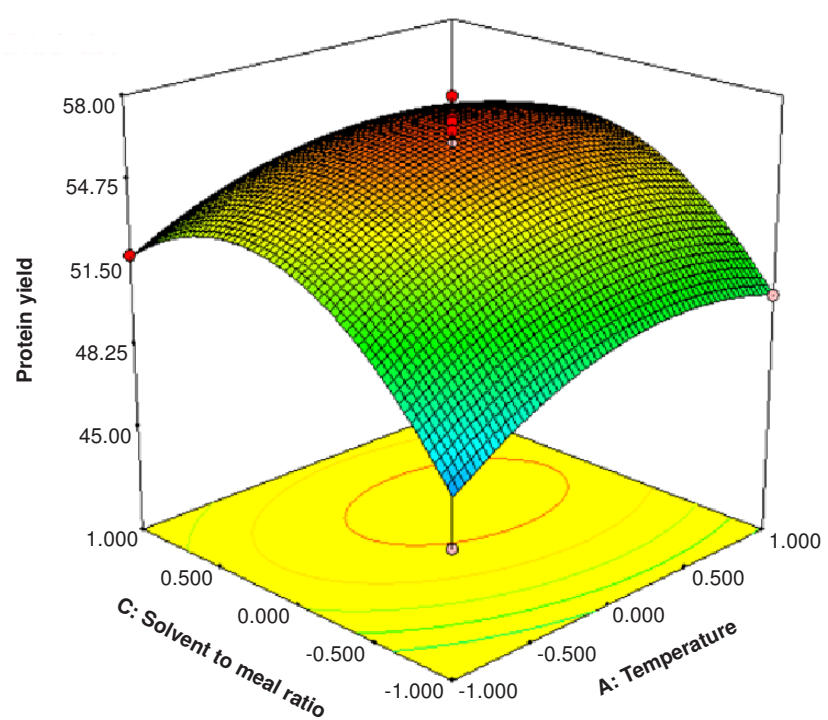

(B)

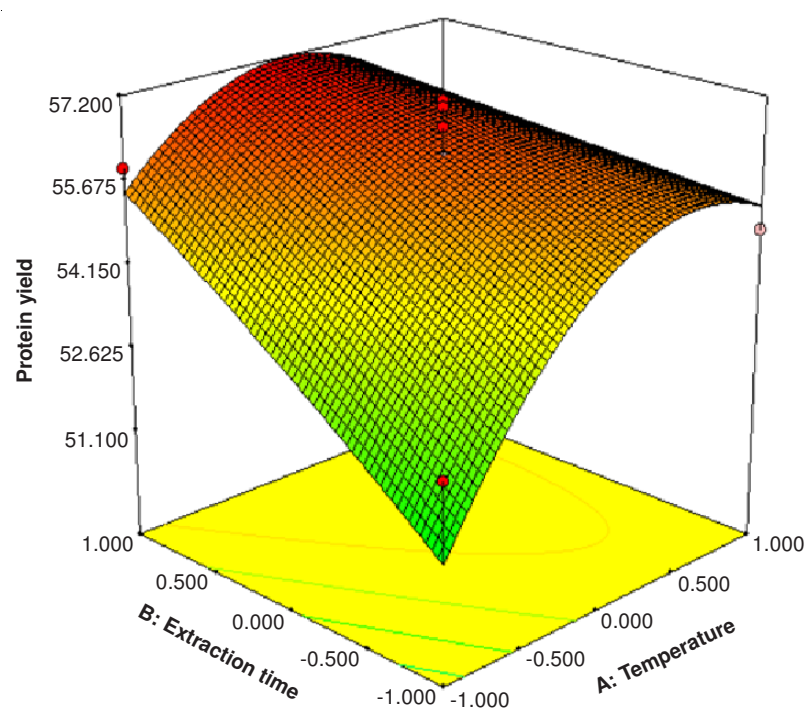

(C)

Fig. 2. 3D graphic surface optimization of protein yield versus: A solvent:solid ratio and extraction time; $\mathrm{B}$ temperature and solvent:solid ratio; $\mathrm{C}$ temperature and extraction time
TABLE-3

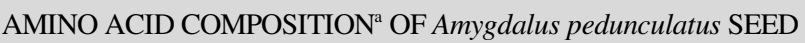
PROTEIN (APSP) AND SPI ${ }^{22}$ (g/100 g PROTEIN)

\begin{tabular}{lccc}
\hline \multicolumn{1}{c}{ Amino acid } & FAO $^{\mathrm{b}}$ & APSP & SPI \\
\hline Aspartic acid & - & $11.61 \pm 0.55$ & $9.09 \pm 0.16$ \\
Glutamic acid & 1.9 & $25.24 \pm 1.02$ & $3.08 \pm 0.03$ \\
Serine & - & $3.61 \pm 0.06$ & $4.17 \pm 0.08$ \\
Histidine & 3.4 & $2.21 \pm 0.21$ & $5.30 \pm 0.17$ \\
Glycine & - & $4.60 \pm 0.08$ & $15.7 \pm 0.18$ \\
Threonine & - & $2.00 \pm 0.10$ & $1.44 \pm 0.05$ \\
Arginine & - & $10.69 \pm 0.16$ & $5.84 \pm 0.28$ \\
Alanine & - & $4.37 \pm 0.07$ & $2.89 \pm 0.07$ \\
Proline & - & $4.21 \pm 0.10$ & $5.86 \pm 0.15$ \\
Tyrosine & $6.3^{\mathrm{c}}$ & $2.91 \pm 0.09$ & $5.53 \pm 0.16$ \\
Valine & 3.5 & $4.54 \pm 0.13$ & $3.52 \pm 0.08$ \\
Methionine & $2.5^{\mathrm{d}}$ & $0.27 \pm 0.02$ & $2.42 \pm 0.13$ \\
Cysteine & - & $0.82 \pm 0.05$ & $1.15 \pm 0.01$ \\
Isoleucine & 2.8 & $3.55 \pm 0.06$ & $3.54 \pm 0.15$ \\
Leucine & 6.6 & $6.71 \pm 0.14$ & $5.77 \pm 0.13$ \\
Phenylalanine & - & $5.06 \pm 0.11$ & $4.69 \pm 0.07$ \\
Lysine & 5.8 & $1.26 \pm 0.03$ & $11.20 \pm 0.19$ \\
Tryptophan & - & $1.09 \pm 0.02$ & $0.50 \pm 0.02$ \\
Total & - & $94.75 \pm 0.99$ & $91.69 \pm 1.00$ \\
\hline
\end{tabular}

${ }^{a}$ Data are the mean \pm SD of three analyses. ${ }^{b} \mathrm{FAO} / \mathrm{WHO} / \mathrm{ONU}$. Energy and protein requirement, 1985 . ${ }^{\mathrm{C}}$ Tyrosine + phenylalanine. ${ }^{\mathrm{d}}$ Methionine + cysteine.

mean values of absorption capacities of Amygdalus pedunculatus seed protein were shown in Table-4. In this experiment, the water absorption capacity was $2.20 \mathrm{~mL} / \mathrm{g}$, which was lower than that reported for casein $(2.48 \mathrm{~mL} / \mathrm{g})^{2}$ and unstabilized rice bran protein isolates (Un-PI) $(3.80 \mathrm{~mL} / \mathrm{g})^{8}$. And it was higher than white rice protein $(1.78 \mathrm{~mL} / \mathrm{g})^{12}$. Aletor et al. ${ }^{24}$ considered that water absorption capacity values ranging from 1.49 to $4.72 \mathrm{~g} / \mathrm{g}$ could be used in viscous foods. The data indicated that Amygdalus pedunculatus seed protein had good capacity for water absorption and could be used in products which was required high water retention. The oil absorption of Amygdalus pedunculatus seed protein was $2.70 \mathrm{~mL} / \mathrm{g}$, which is higher than white rice protein $(2.56 \mathrm{~mL} / \mathrm{g})^{12}$, casein $(2.15$ $\mathrm{mL} / \mathrm{g})^{2}$ and Un-PI $(2.40 \mathrm{~mL} / \mathrm{g})^{8}$. High oil absorption is essential in the formulation of many processed foods and then improves mouthfeel and flavor retention of the final product.

Protein solubility (PS): In general, superior functional attributes for most applications in food processing were associated with the solubility of proteins. It was depicted in Fig. 3 that Amygdalus pedunculatus seed protein exhibited $\mathrm{pH}$ dependent protein solubility. The solubility of Amygdalus pedunculatus seed protein was the minimum at $\mathrm{pH} 4$, which might be due to the isoelectric region. Under isoelectric $\mathrm{pH}$, the electrostatic repulsion and ionic hydration were minimum and hydrophobic interactions between surface non-polar patches were maximum ${ }^{25}$. The protein solubility increased on either side of $\mathrm{pH} 4$ including acidic and alkaline. A moderate increase was observed above $\mathrm{pH} 4$ until $\mathrm{pH} 8$, followed by a marked increase up to $\mathrm{pH} 10$. At lower $\mathrm{pH}$ values, the increased net positive charge contribute to the solubility ${ }^{6}$. At higher $\mathrm{pH}$ values, the solubility increased may be due to the increased net negative charge on the protein dissociates the protein aggregates ${ }^{26}$. The total contents of negatively charged amino acids (aspartic acid and glutamic acid) of Amygdalus pedunculatus seed protein were $36.85 \%$. The residues of these 
TABLE-4

PHYSICO-CHEMICAL ${ }^{\text {a }}$ PROPERTIES OF Amygdalus pedunculatus SEED PROTEIN

\begin{tabular}{|c|c|c|c|c|c|c|c|c|c|}
\hline Index & \multicolumn{9}{|c|}{ Amygdalus pedunculatus seed protein } \\
\hline Water absorption $(\mathrm{mL} / \mathrm{g})$ & \multicolumn{9}{|c|}{$2.20 \pm 0.16$} \\
\hline Oil absorption (mL/g) & \multicolumn{9}{|c|}{$2.70 \pm 0.21$} \\
\hline Surface hydrophobicity $\left(\mathrm{S}_{0}\right)$ & \multirow{2}{*}{\multicolumn{9}{|c|}{$290 \pm 8$}} \\
\hline Gelation & & & & & & & & & \\
\hline Concentration & $\begin{array}{c}2 \% \\
(-)\end{array}$ & $\begin{array}{c}4 \% \\
(-)\end{array}$ & $\begin{array}{c}6 \% \\
(-)\end{array}$ & $\begin{array}{c}8 \% \\
(-)\end{array}$ & $\begin{array}{c}10 \% \\
( \pm)\end{array}$ & $\begin{array}{c}12 \% \\
(+)\end{array}$ & $\begin{array}{c}14 \% \\
(+)\end{array}$ & $\begin{array}{c}16 \% \\
(+)\end{array}$ & $\begin{array}{c}18 \% \\
(+)\end{array}$ \\
\hline Least gelation concentration & \multicolumn{9}{|c|}{12} \\
\hline
\end{tabular}

${ }^{\mathrm{a}}$ Gelation levels: $(-)$ liquefied, $( \pm)$ gluey and $(+)$ gel. The values are the mean of three replicates.

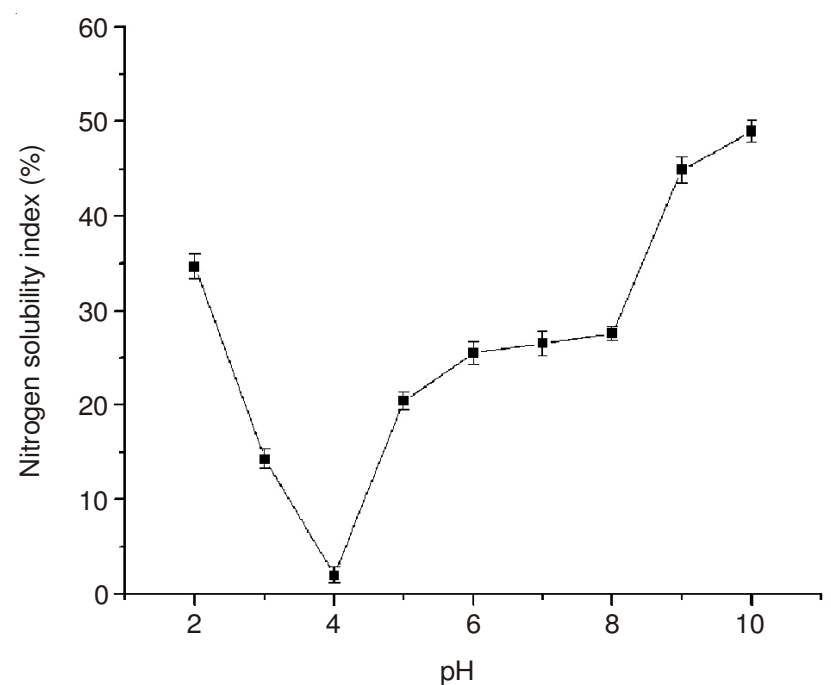

Fig. 3. Protein solubility of Amygdalus pedunculatus seed protein. Data are shown as means. Error bars represent the SD

ionic amino acids might be at least partially responsible for the protein solubility at high $\mathrm{pH}$ levels.

Foaming properties: The foaming capacity of Amygdalus pedunculatus seed protein (Fig. 4A) was pH-dependent. At pH 4 the lowest foaming capacity ( $9 \%$ ) which was due to the protein behaviour at its isoelectric point. On either side of $\mathrm{pH}$ 4, foaming capacity significantly increased, especially at 10 . It was probably due to the net charges' increase on the protein surface, which weakened the hydrophobic interactions but increased the flexibility of the protein. This allowed the protein to diffuse more rapidly to the air-water interface to encapsulate air particles and then enhance the foam formation ${ }^{26}$. The effect of $\mathrm{pH}$ on foaming stability of Amygdalus pedunculatus seed protein was shown in Fig. 4B. It was found that Amygdalus pedunculatus seed protein had a minimum foaming stability $(50 \%)$ at $\mathrm{pH} 4$ with an increase on both sides of $\mathrm{pH} 4$. Foaming stability was dependent on the formation of a thick cohesive layer around the air bubble ${ }^{25}$.

Emulsifying properties: Emulsifying activity and emulsifying stability were used to depicted the emulsifying properties of food proteins. The effect of $\mathrm{pH}$ on emulsifying activity and emulsifying stability of Amygdalus pedunculatus seed protein were shown in Fig. 5. Results showed that Amygdalus pedunculatus seed protein had a minimum emulsifying activity (40.2\%) at pH 4 (Fig. 5A) with an increase on both sides of $\mathrm{pH}$ 4. Emulsifying activity was pH-dependent and alkaline $\mathrm{pH}$ improved the emulsifying activity more than did the acidic $\mathrm{pH}^{27}$. Similar observations on the $\mathrm{pH}$ dependence of emulsi-
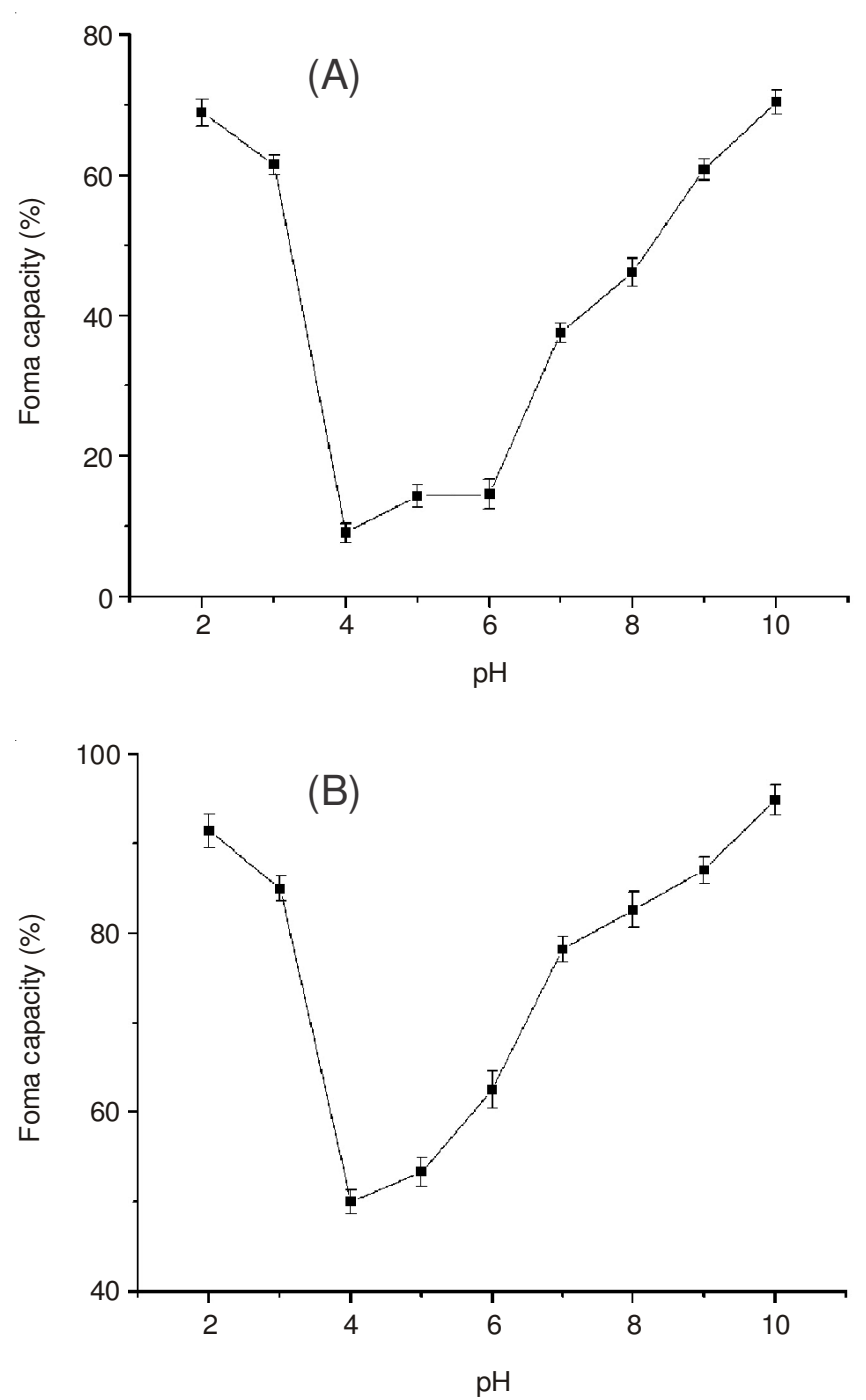

Fig. 4. Effects of $\mathrm{pH}$ on foaming capacity and foaming stability of Amygdalus pedunculatus seed protein. Data are shown as means. Error bars represent the SD

fying activity have been reported ${ }^{28}$. Nakai indicated that protein solubility and its surface hydrophobicity were very important properties for determining protein emulsifying activity ${ }^{28}$. Moreover, the relationship between emulsifying activity against $\mathrm{pH}$ for Amygdalus pedunculatus seed protein was more or less similar to that between protein solubility against $\mathrm{pH}$. This was in agreement with the general correlation between emulsifying activity and protein solubility found in previous studies $^{29,30}$. emulsifying stability was also $\mathrm{pH}$-dependent (Fig. 5B). Hung and Zayas ${ }^{30}$ suggested that various factors, 

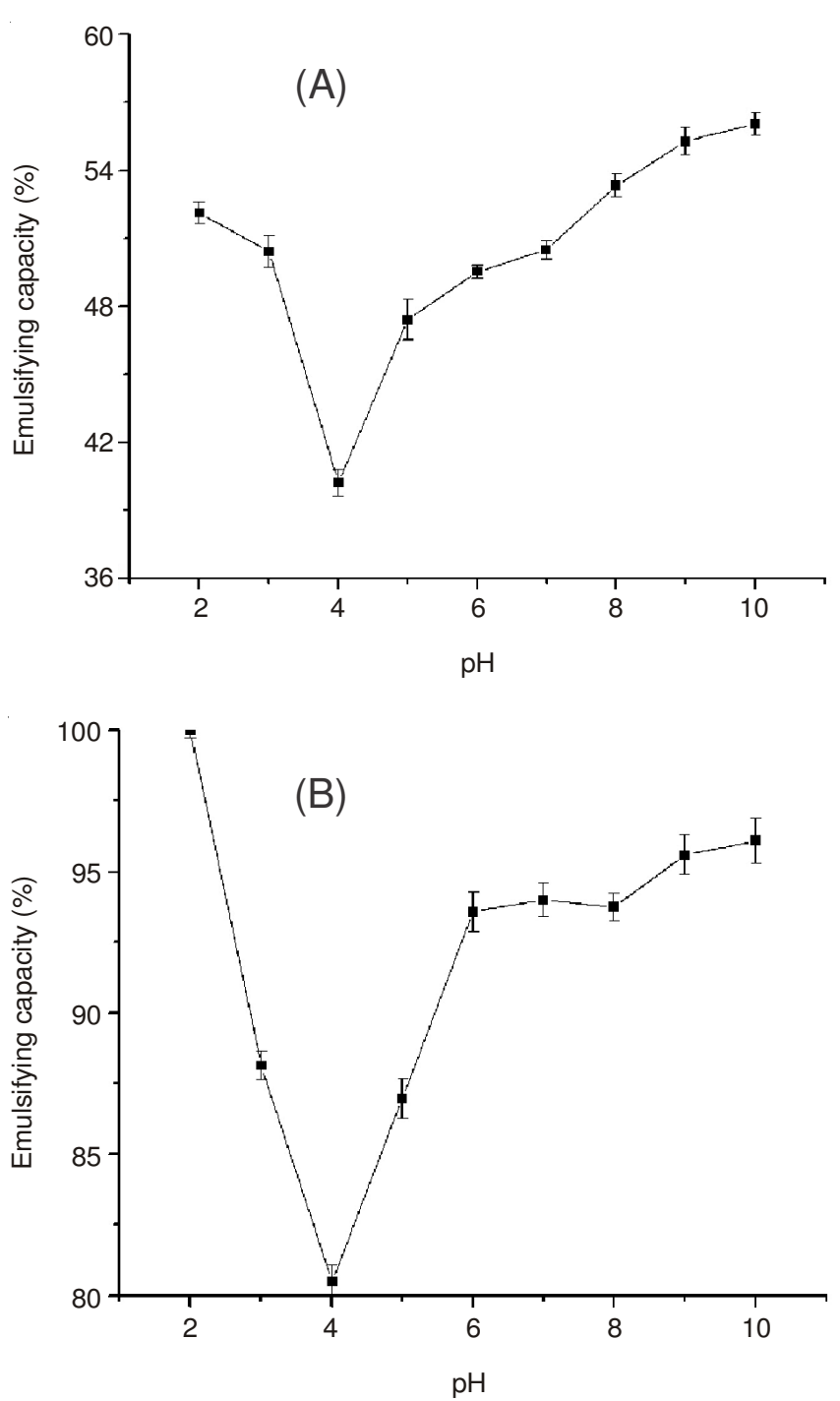

Fig. 5. Effects of $\mathrm{pH}$ on emulsifying activity and emulsifying stability of Amygdalus pedunculatus seed protein. Data are shown as means. Error bars represent the SD

including $\mathrm{pH}$, net charge, heat treatment and protein conformation, could affect the values of emulsifying stability. The high emulsifying stability of protein isolates might be due to the partial unfolding of protein structure, by exposing hydrophobic units and facilitating protein interaction with nonpolar solvents and resisting oil drop flocculation, thereby increasing the overall stability of emulsion ${ }^{8}$. Present study of emulsifying activity and emulsifying stability were quite similar to those reported earlier by Jiamyangyuen et al. ${ }^{31}$.

Least gelation concentration: It is an important functional property that the proteins' ability to form gels in food processing and formulation. The gel is resistant to flow under pressure when proteins form a three-dimensional network, in this case gelation occurs. The least gelation concentration is often used as an indication of the gelation capacity of food proteins ${ }^{19}$. The gelling properties of Amygdalus pedunculatus seed protein was summarized in Table-4. There was no gel formed at a concentration of 2, 4, 6 and $8 \%(w / v)$. A weak gel was formed at $10 \%$ concentration of Amygdalus pedunculatus seed protein. At $12 \%$ (least gelation concentration), a strong gel was formed. Amygdalus pedunculatus seed protein had the best gelling properties compared with the rice bran protein ${ }^{8}$ yellow pea protein and kabuli chickpea protein (least gelation concentration of $14 \%, \mathrm{w} / \mathrm{v})^{19}$. The results might be due to the denaturation of protein and the reinforcement of gel strength that made lower least gelation concentration values of Amygdalus pedunculatus seed protein which had good gelation characteristics. Amygdalus pedunculatus seed protein would be a useful additive and it could deliver the desired gelling property in thick textured foods.

Surface hydrophobicity (So): Surface hydrophobicity is affected by the presence of hydrophobic patches on the surface of proteins that are available to interact with the food system, especially molecules in polar aqueous environments ${ }^{8}$. The surface hydrophobicity value of Amygdalus pedunculatus seed protein was presented in Table-4. Surface hydrophobicity of Amygdalus pedunculatus seed protein (290) was significantly higher than that of parboiled rice bran protein isolates $(29)^{8}$, but lower than SPI (399) $)^{22}$. This demonstrated that Amygdalus pedunculatus seed protein had more hydrophobic grouping on the surface of protein. The functional property of a protein might be impacted by higher surface hydrophobicity, especially in foam and emulsion where this property is needed for a specific food product application ${ }^{32}$.

\section{Conclusion}

The results of the present study provided significant information on the physicochemical and functional aspects of protein extracted from Amygdalus pedunculatus seed. Response surface methodology results gave the optimum value of temperature, extraction time and liquid: solid ratio at $39.49^{\circ} \mathrm{C}, 80$ min and 15.88:1, respectively. The amino acid composition of the Amygdalus pedunculatus seed protein was also determined that the high glutamic acid content $(25.24 \%)$ and total amino acids (94.75\%) were obtained. Finally, Amygdalus pedunculatus seed protein demonstrated lower protein solubility, but higher oil absorption capacity and surface hydrophobicity etc. The data obtained from this study could provide basic information for the food application of Amygdalus pedunculatus seed protein which has not been explored earlier for its functional property, such as it can be used for sausages, puddings, baked food and creams.

\section{ACKNOWLEDGEMENTS}

This work was financially supported by Science and Technology Innovation Project Coordination of Shaanxi Province (grant No. 2012KTCL03-05), Science and Technology Innovation Project Coordination of Shaanxi Province (grant No. 2011KTCL03-04).

\section{REFERENCES}

1. L.Q. Shen, X.Y. Wang, Z.Y. Wang, Y.F. Wu and J.S. Chen, Food Chem., 107, 929 (2008).

2. G.K. Chandi and D.S. Sogi, J. Food Eng., 79, 592 (2007).

3. S. Gorinstein, E. Pawelzlk, E.D. Licon, R. Haruenkit, M. Weisz and S. Trakhtenberg, J. Sci. Food Agric., 82, 886 (2002).

4. A. Rangel, G.B. Domont, C. Pedrosa and S.T. Ferriera, J. Agric. Food Chem., 51, 5792 (2003).

5. D.S. Sogi, S.K. Garg and A.S. Bawa, J. Food Sci., 67, 2997 (2002).

6. H. Tomotake, I. Shimaoka, J. Kayashita, M. Nakajoh and N. Kato, J. Agric. Food Chem., 50, 2125 (2002). 
7. M. Wang, N.S. Hettiarachchy, M. Qi, W. Burks and T. Siebenmorgen, J. Agric. Food Chem., 47, 411 (1999).

8. S.H. Khan, M.S. Butt, M.K. Sharif, A. Sameen, S. Mumtaz and M.T. Sultan, J. Agric. Food Chem., 59, 2416 (2011).

9. C. Cardoso, B. Ribeiro and R. Mendes, Eur. Food Res. Technol., 234, 935 (2012)

10. J. Zheng, H.T. Wu, B.W. Zhu, X.P. Dong, M.M. Zhang and Y.L. Li, Eur. Food Res. Technol., 234, 895 (2012).

11. M.M.M. Oliveira, D.F. Brugnera, J.A. Nascimento, N.N. Batista and R.H. Piccoli, Eur. Food Res. Technol., 234, 821 (2012).

12. X.H. Cao, H.B. Wen, C.J. Li and Z.X. Gu, J. Cereal Sci., 50, 184 (2009).

13. P.J. Shand, H. Ya, Z. Pietrasik and P.K.J.P.D. Wanasundara, Food Chem., 83, 1119 (2007).

14. M.J. Lin, E.S. Humbert and F.W. Sosulski, J. Food Sci., 39, 368 (1974).

15. M. Naczk, L.L. Diosady and L.J. Rubin, J. Food Sci., 50, 1685 (1985).

16. S.K. Sathe and D.K. Salunkhe, J. Food Sci., 46, 71 (1981).

17. K.O. Adebowale and O.S. Lawal, Food Chem., 83, 237 (2003).

18. U. Kalapathy, N.S. Hettiarachchy and K.C. Rhee, J. Am. Oil. Chem. Soc., 74, 195 (2006)

19. J.I. Boye, S. Aksay, S. Roufik, S. Ribereau, M. Mondor, E. Farnworth and S.H. Rajamohamed, Food Res. Int., 43, 537 (2010).

20. T.A. El-Adawy and K.M. Taha, J. Agric. Food Chem., 4, 1253 (2001).

21. I.Y.S. Rustom, M.H. Lopez-Leiva and B.M. Nair, J. Food Sci., 56, 1660 (1991)
22. R. Horax, N. Hettiarachchy, A. Kannan and P.Y. Chen, Food Chem., 124, 545 (2011).

23. J.Y. Cheng, S.H. Zhou, D. Wu, J.C. Chen, D.H. Liu and X.Q. Ye, Food Chem., 112, 469 (2009).

24. O. Aletor, A.A. Oshodi and K. Ipinmoroti, Food Chem., 78, 63 (2002).

25. S. Damodaran, In ed.: S. Damodaran, Food Proteins and their Applications, Institute National de la Recherche Agronomique Centre de Recherches de Tours Nouzilly, France; Marcel Dekker, Inc: New York (1997).

26. R.E. Aluko and R.Y. Yada, Food Chem., 53, 259 (1995).

27. E.K. Khalid, E.E. Babiker and A.H. El-Tinay, Food Chem., 82, 361 (2003).

28. S. Nakai, J. Agric. Food Chem., 31, 676 (1983).

29. D.D. Crenwelge, C.W. Dill, P.T. Tybor and W.A.A. Landmann, J. Food Sci., 39, 175 (1974).

30. S.C. Hung and J.F. Zayas, J. Food Sci., 56, 12163 (1991).

31. S. Jiamyangyuen, W.J. Harper, V. Srijesdaruk and K. Kumthonglang, Milchwissenschaft, 60, 192 (2005).

32. S.H. Guzmán-Maldonado and O. Paredes-López, In ed.: O. ParedesLópez, Molecular Biotechnology for Plant Food Production, Technomic Publishing, Lancaster (1999). 